\title{
First species of Ophiotaenia (Cestoda: Proteocephalidea) from Madagascar: $O$. georgievi sp. n., a parasite of the endemic snake Leioheterodon geayi (Colubridae)
}

\author{
Alain de Chambrier ${ }^{1}$, Morgane Ammann ${ }^{1,2}$ and Tomáš Scholz ${ }^{3}$ \\ ${ }^{1}$ Natural History Museum, Department of Invertebrates, P.O. Box 6434, 1211 Geneva 6, Switzerland; \\ ${ }^{2}$ University of Geneva, Faculty of Science, Department of Zoology and Animal Biology, Quai Ernest-Ansermet 30, \\ 1211 Geneva 4, Switzerland; \\ ${ }^{3}$ Institute of Parasitology, Biology Centre of the Academy of Sciences of the Czech Republic, Branišovská 32, 37005 České \\ Budějovice, Czech Republic
}

\begin{abstract}
Ophiotaenia georgievi sp. n. (Proteocephalidea: Proteocephalinae) is described from the intestine of endemic colubrid snake Leioheterodon geayi Mocquard (Colubridae) from Antananarivo in Madagascar. The new species is the first species of Ophiotaenia La Rue, 1911 reported from Madagascar. It differs from all Ophiotaenia species parasitic in African snakes in the possession of a three-layered embryophore of eggs (other African species have two-layered embryophore). Furthermore, O. georgievi can be distinguished by the number of testes (92-140), width of the scolex $(225-235 \mu \mathrm{m})$, total body length $(57 \mathrm{~mm})$, cirrus-sac length/ proglottis width ratio (19-32\%), and number of lateral uterine diverticula (23-28 on each side). Ophiotaenia georgievi represents the second proteocephalidean cestode reported from Madagascar, the first one being Deblocktaenia ventosaloculata (Deblock, Rosé et Broussart, 1962), a parasite from Ithycyphus miniatus. A list of Ophiotaenia species parasitic in venomous and non-venomous snakes is provided and possible existence of other new congeneric species in snakes from Madagascar is discussed.
\end{abstract}

Keywords: Eucestoda, Proteocephalidea, Ophiotaenia georgievi, morphology, Ophidia, helminths

Tapeworms of the order Proteocephalidea Mola, 1928 are frequent and widely distributed parasites of freshwater fishes, amphibians and reptiles (Rego 1994). In Africa, most proteocephalidean cestodes were described in the first half of the last century (Schmidt 1986) and they parasitize mainly catfishes (de Chambrier et al. 2007, 2009, Scholz et al. 2009). Madagascar is the largest island in Africa and due to its isolation, it hosts extraordinary flora and fauna with high proportion of endemic taxa (see Vences et al. 2009 for review). This is also true for reptiles, with as many as 300 species described, over $90 \%$ of them being endemic (Vences et al. 2009). However, the information on their parasites is very limited and only one species of proteocephalidean cestode, Deblocktaenia ventosaloculata (Deblock, Rosé et Broussart, 1962), has been reported from Madagascar. In this paper, a new proteocephalidean is described from the endemic colubrid snake Leioheterodon geayi Mocquard.

\section{MATERIALS AND METHODS}

The worms studied were collected by G. Brygoo, deputy director (1954-1962) and director (1962-1974) of the Madagascar Pasteur Institute. His collection of tapeworms from snakes in
Madagascar was first deposited in the Institute of Zoology in Neuchâtel, Switzerland and then transferred to the Natural History Museum in Geneva. Cestodes were stained with Schuberg's hydrochloric carmine, dehydrated in an ethanol series, cleared with eugenol (clove oil) and mounted in Canada balsam. Pieces of the strobila were embedded in paraffin wax, cross-sectioned (thickness 12-15 $\mu \mathrm{m}$ ), stained with Weigert's haematoxylin and counterstained with 1\% acidic eosin B (Scholz and Hanzelová 1998, de Chambrier 2001).

Scolex for scanning electron microscopical (SEM) observation was dehydrated in a graded ethanol series $(80 \%, 96 \%$, twice $100 \%$ ), then transferred to a graded amyl acetate series, critical point-dried in $\mathrm{CO}_{2}$, sputter coated with gold and examined with a Zeiss 940A electron microscope at the Natural History Museum, Geneva. Eggs were studied in distilled water. Microthrix terminology follows Chervy (2009). All measurements are given in micrometres $(\mu \mathrm{m})$ unless otherwise stated. Abbreviations used in the description are as follows: $\mathrm{x}=$ mean; $\mathrm{n}=$ number of measurements; $\mathrm{CV}=$ coefficient of variability $(\mathrm{SD} / \mathrm{x} \times 100$; in $\%)$ OV $=$ ratio of the width of the ovary to the width of the proglottis; $\mathrm{PP}=$ position of genital pore (cirrus pore) expressed as percentage of its position to the proglottis length; $\mathrm{CS}=$ relative size of the of cirrus-sac expressed as percentage of its length to the width of the proglottis. MHNG INVE = Natural History Museum Geneva, Invertebrate Collection; IPCAS = Institute 
of Parasitology, BC AS, České Budějovice, Czech Republic; $\mathrm{BMNH}=$ The Natural History Museum, London, UK.

\section{RESULTS}

\section{Ophiotaenia georgievi sp. n.}

Figs. 1-14

Description (based on five specimens): Proteocephalidae, Proteocephalinae. Cestodes up to $57 \mathrm{~mm}$ long; maximum width 500. Strobila acraspedote, anapolytic, consisting of 36-39 $(n=3)$ proglottides: $25-28$ immature (up to appearance of spermatozoa in vas deferens), 3 mature (up to appearance of eggs in uterus), 7-11 pregravid (up to appearance of hooks in oncospheres). Gravid proglottides found detached from strobila.

Immature and mature proglottides wider than long to longer than wide (length:width ratio 0.11-1.69), pregravid and gravid proglottides longer than wide (length:width ratio 1.03-3.34). Scolex 140-160 $(\mathrm{n}=2)$ long and 225$235(\mathrm{n}=3)$ wide, slightly wider than neck (Figs. 1-3, 5). Suckers uniloculate, round, slightly embedded, 100-125 $(\mathrm{x}=55, \mathrm{n}=8)$ in diameter, representing $44-53 \%$ of scolex width (Fig. 3). Apical organ absent (Fig. 5). Proliferation zone 5-6 mm $(\mathrm{x}=5.5 \mathrm{~mm} ; \mathrm{n}=2)$ long and 160-200 wide.

Internal longitudinal musculature well developed, formed by small bundles of numerous muscle fibres (Figs. 7-9) forming anastomoses. Ventral osmoregulatory canals reach laterally vitelline follicles, 20-30 in diameter; dorsal canal narrow, only 2-4 in diameter, situated alongside testicular fields (Figs. 11, 12).

Testes medullary, in one layer, forming two narrow lateral bands (poral field separated by terminal genitalia to preporal and postporal groups). Testes may reach anterior margin of proglottis, but never reach to ovary, occupying $5 / 6$ of total length of proglottis (Figs. 11, 12). Testes $92-140(\mathrm{x}=115, \mathrm{n}=18, \mathrm{CV}=10 \%)$ in number, with $48-70(\mathrm{x}=60)$ aporal testes, $22-40(\mathrm{x}=30)$ preporal testes and $18-32(\mathrm{x}=25)$ postporal testes. Testes spherical, 23-38 $(x=29, n=15)$, present also in gravid proglottides (Figs. 11, 12).

Cirrus-sac elongate to pyriform, thick-walled, 130-180 $(\mathrm{x}=150, \mathrm{n}=14)$ long and 55-100 $(\mathrm{x}=80, \mathrm{n}=14)$ wide (Fig. 6); CS 19-32\% ( $\mathrm{x}=26 \%, \mathrm{n}=14, \mathrm{CV}=14 \%)$. Cirrus robust, its length representing about $80 \%$ of cirrussac length. Vas deferens strongly coiled, situated between proximal part of cirrus-sac and midline of proglottides, but never crossing it.

Genital atrium present; genital pores alternating irregularly, more or less equatorial, $\mathrm{PP}=44-56 \%(\mathrm{x}=51 \%$, $\mathrm{n}=14, \mathrm{CV}=2 \%$ ) (Figs. 11, 12). Genital ducts passing between osmoregulatory canals.

Ovary medullary, bilobed (Figs. 11, 12), 360-510 $(\mathrm{x}=400, \mathrm{n}=14)$ wide, $\mathrm{OV}=71-76 \%(\mathrm{x}=74 \% ; \mathrm{n}=14$; $\mathrm{CV}=4 \%)$. Mehlis' glands $65-85(\mathrm{x}=77, \mathrm{n}=10)$ in diameter, representing $13-15 \%$ of proglottis width (Fig. 12).
Vitelline follicles medullary, arranged in two lateral fields near margins of proglottides, occupying 91-96\% $(\mathrm{x}=93 \%, \mathrm{n}=11)$ of proglottis length, interrupted on both sides at level of cirrus-sac (Fig. 12).

Vaginal canal forming small seminal receptacle anterodorsal to ovarian isthmus; canal slightly coiled just anterior to seminal receptacle (Fig. 11). Terminal part of vaginal canal (pars copulatrix vaginae) surrounded by large vaginal sphincter and chromophilic cells (Fig. 6). Vagina anterior $(24 \% ; n=25)$ or posterior $(76 \%)$ to cirrus-sac.

Primordium of uterine stem medullary, present in immature proglottides. Development of uterus of type 1 according to de Chambrier et al. (2004): in immature proglottides, uterine stem straight, occupying most length of proglottis but never crossing ovarian isthmus, formed by wide longitudinal band of chromophilic cells situated along midline of proglottides. Lumen of uterus appearing in first mature proglottides (Fig. 11); diverticula (lateral branches) formed before first eggs appear in uterine stem. In pregravid proglottides, uterus occupying up to $25 \%$ of proglottis width, with $23-28(\mathrm{x}=25)$ thin-walled lateral diverticula on each side. In gravid proglottides, diverticula occupying up to $48 \%$ of proglottis width. Uteroduct entering uterus almost at level of ovary isthmus.

Eggs round, with outer envelope collapsed in whole mounts (Figs. 10, 13, 14). Embryophore spherical, with thick supplementary spherical layer between outer envelope and oncosphere, thus forming three-layered embryophore; internal layer 14-20 $(\mathrm{n}=22)$ in diameter, middle layer $25-29(\mathrm{n}=22)$ in diameter; external layer 31-35 $(\mathrm{n}=22)$ in diameter; oncosphere spherical, 10-14 in diameter $(n=6)$, with three pairs of hooks, 5-6 long (Figs. 10, 13, 14).

Type host: Leioheterodon geayi Mocquard, 1905 (Ophidia, Colubridae).

Site of infection: Intestine.

Type locality: Antananarivo (18 $\left.55^{\prime} \mathrm{S}, 47^{\circ} 31^{\prime} \mathrm{E}\right)$, Madagascar, April 1968.

Type material: Holotype MHNG INVE 65470 (field number 27/68) (two slides) and three paratypes: MHNG INVE 65471, immature, on the same slide as the holotype; MHNG INVE 65472, on the same slide as the holotype, the scolex in serial frontal sections (one slide); MHNG INVE 65473, eight slides (two whole-mounts and six slides of serial cross-sections); MHNG INVE 65474, one scolex mounted for SEM observations; BMNH 2010.7.26.1 - paratype, one slide of serial cross-sections (from MHNG INVE 65473); IPCAS C-564/1 - paratype, one slide of serial cross-sections (from MHNG INVE 65473); all with field number 27/68.

Other material: MHNG INVE 65475-65477, IPCAS C-564/1, BMNH 2010.7.26.1, 29 slides of cross-sections, one frontal section of the scolex, field number $27 / 68$. Some pieces in alcohol, MHNG INVE 65475 (field number 27/68).

Etymology: The new species is named in honour of Prof. Boyko B. Georgiev (Sofia, Bulgaria), for his outstanding contribution to cestode systematics. 
Remarks. The new species is placed in Ophiotaenia La Rue, 1911 (Proteocephalinae) because of the medullary position of the vitellarium, unarmed scolex, uniloculate suckers and testes forming two separate fields (Schmidt 1986). Ninety-four species of Ophiotaenia parasitizing reptiles and amphibians are currently recognized as valid (see species lists in Ammann and de Chambrier 2008, Marsella and de Chambrier 2008, Coquille and de Chambrier 2008); out of these, 63 species are parasites of snakes (Ophidia) (Table 1).

The new species is differentiated from the species occurring in Africa, because it is known that Ophiotaenia tapeworms are limited in their distribution to individual continents and/or zoogeographical regions (Freze 1965). In Africa, 13 Ophiotaenia species have been described from snakes, but two of them are considered as species inquirendae (see Freze 1965 and Table 1).

Ophiotaenia georgievi differs from all Ophiotaenia species parasitic in African snakes in the possession of a third layer of the egg embryophore (Figs. 10, 13). This layer is situated external to the oncosphere, i.e. it forms the internal envelope of the embryophore (Conn and Świderski 2008). According to the literary data and based on own observations of numerous species of Ophiotaenia (A. de Chambrier - unpublished data), the eggs of all African taxa described until now possess only two-layered embryophore (Beddard 1913, Rudin 1917, Fuhrmann 1924, Sandground 1928, Hilmy 1936, Southwell and Lake 1939, Mettrick 1960, 1963, Freze 1965).

A similar structure, i.e. an additional layer of the embryophore, was first observed in Kapsulotaenia sandgroundi (Carter, 1943), a parasite of Varanus komodoensis in Indonesia, and in several species of Ophiotaenia from snakes and lizards in Australia, namely Ophiotaenia longmani Johnston, 1916; O. gallardi (Johnston, 1911); O. amphiboluri (Nybelin, 1917); and O. mjobergi (Nybelin, 1917); and in O. alessandrae Marsella et de Chambrier, 2008 from the frog Hyla boans from Ecuador and Kapsulotaenia cf. saccifera (Ratz, 1900) from monitor (Varanus sp.) in Papua New Guinea (see de Chambrier 2006, Marsella and de Chambrier 2008; unpublished data). All these species occur in distant zoogeographical regions compared to $O$. georgievi and thus are not considered in its differential diagnosis.

Ophiotaenia georgievi can also be distinguished from O. adiposa Rudin, 1917; O. gabonica (Beddard, 1913); O. nigricollis Mettrick, 1963; O. southwelli Freze, 1965; O. theileri Rudin, 1917; and O. zschokkei Rudin, 1917, all parasitic in African snakes, by a lower number of testes (up to 140 in O. georgievi) (Table 2). Unlike some groups

Figs. 1-4. Ophiotaenia georgievi sp. n.; scanning electron micrographs. Paratype (MHNG INVE 65474). Fig. 1. Scolex, dorsoventral view. Fig. 2. Scolex, lateral view. Fig. 3. Scolex, apical view. Fig. 4. Microtriches at the level of the apex of scolex. Scale bars: Figs. $1-3=50 \mu \mathrm{m}$; Fig. $4=3 \mu \mathrm{m}$.

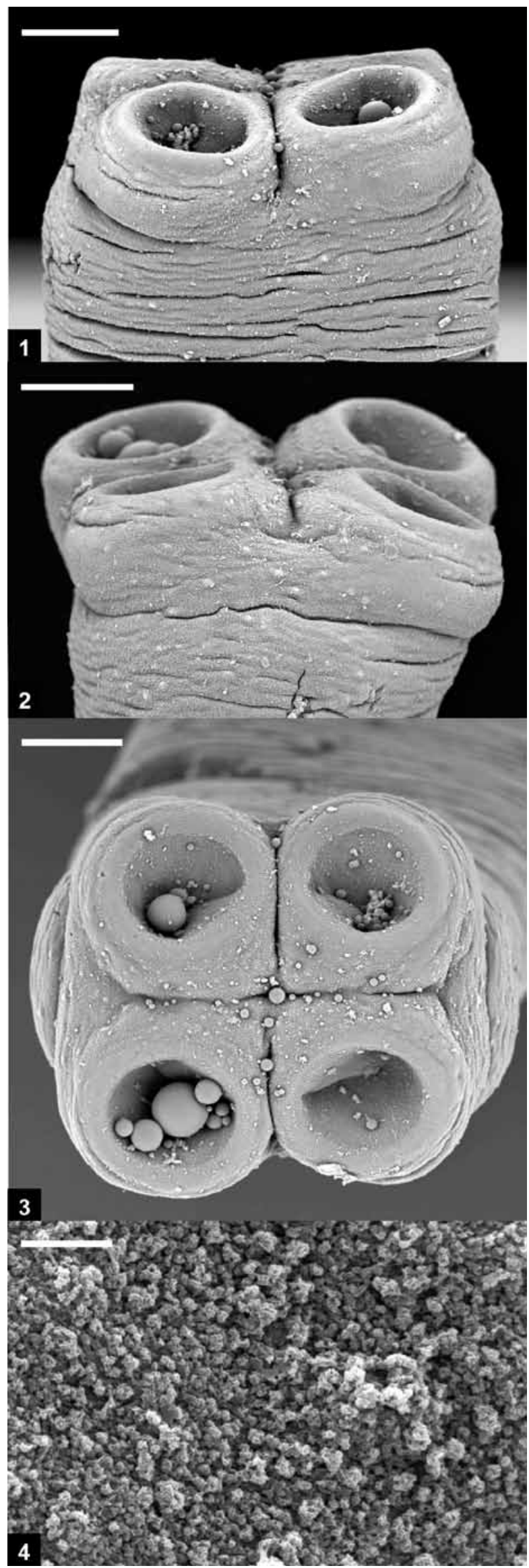




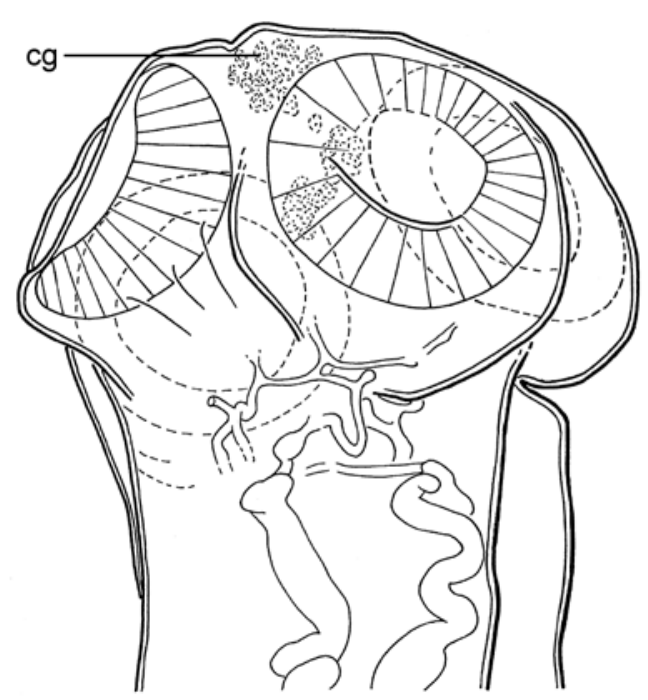

5
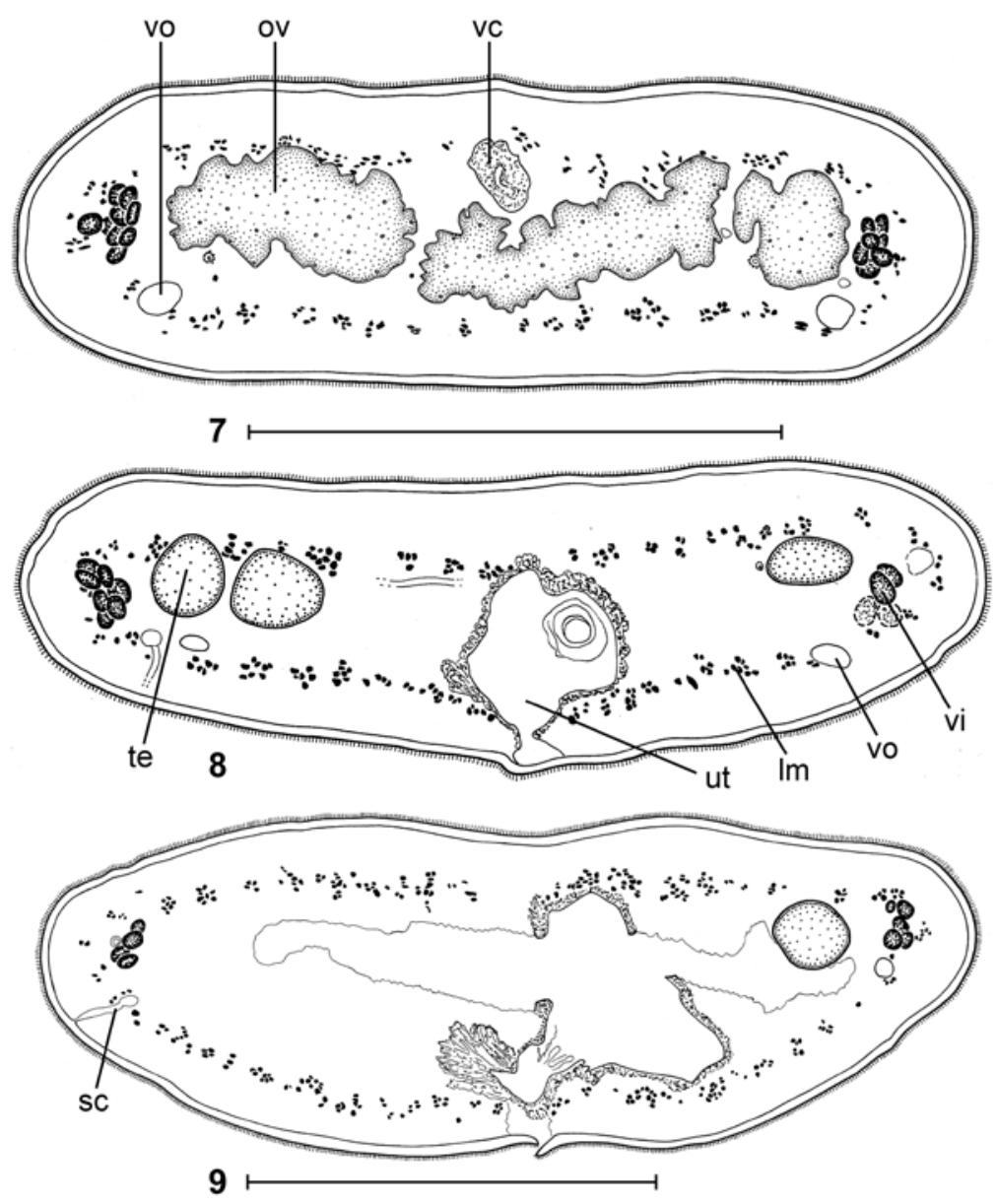

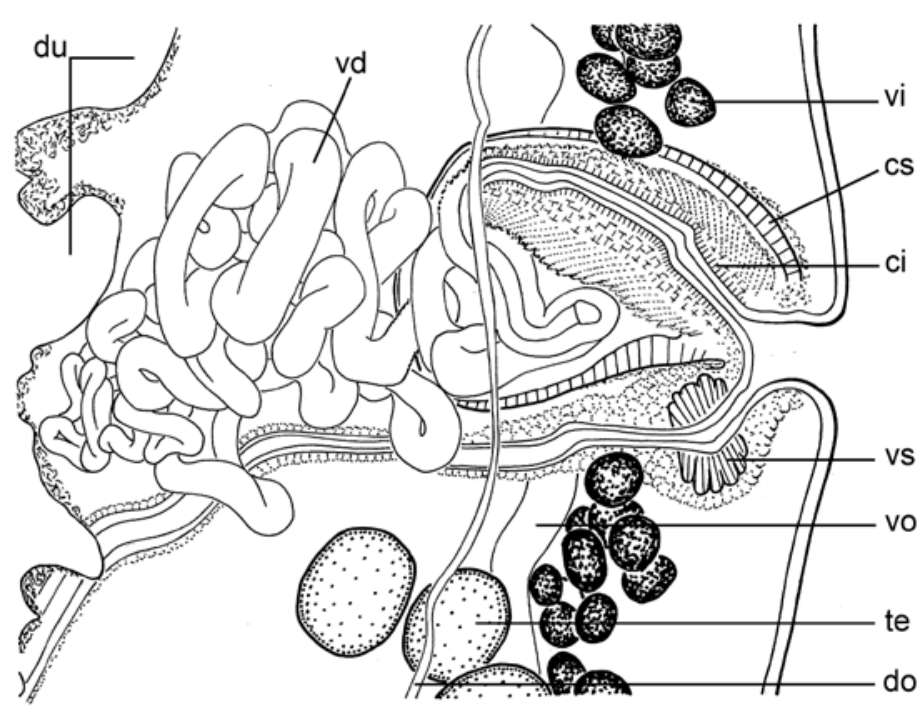

6

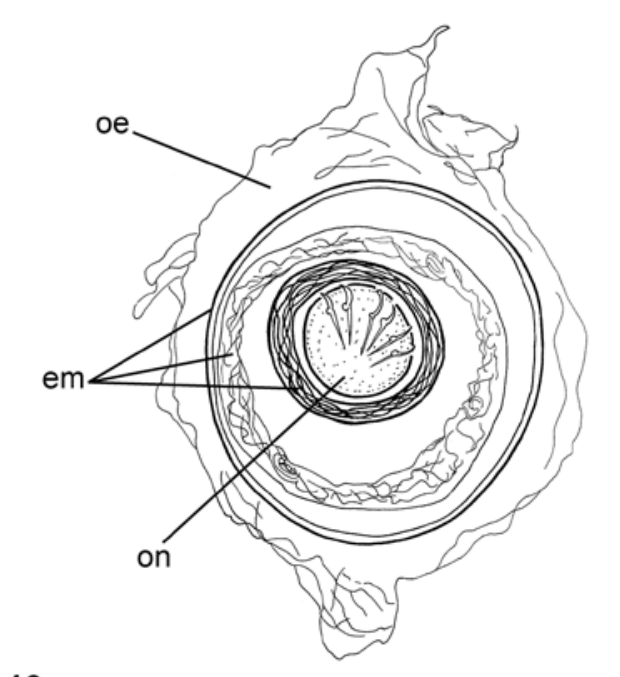

10

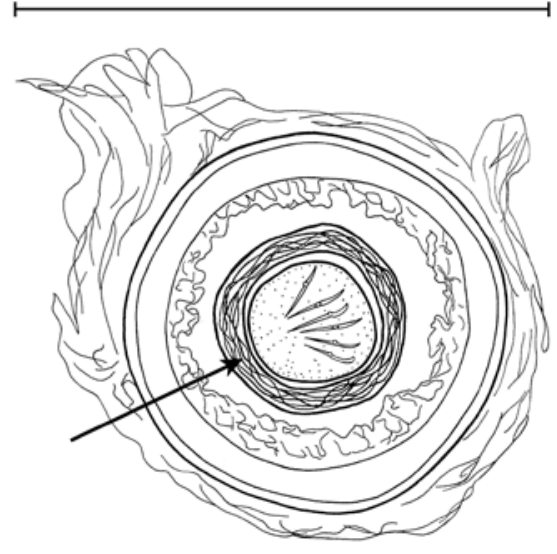

Figs. 5-10. Ophiotaenia georgievi sp. n. Fig. 5. Holotype, scolex, lateral view (MHNG INVE 65470). Fig. 6. Paratype, vagina and cirrus-sac region, dorsal view (MHNG INVE 65473). Figs. 7-9. Cross-sections at the level of the ovary, the anterior part and the posterior part of the testicular region, respectively (MHNG INVE 65475). Fig. 10. Eggs, drawn in distilled water, showing the threelayered embryophore (MHNG INVE 65475); an additional layer marked by an arrow. Abbreviations: cg - cells with finely granular cytoplasm; ci - cirrus; cs - cirrus-sac; do - dorsal osmoregulatory canal; du - uterine diverticles; em - embryophore; lm - internal longitudinal musculature; oe - outer envelope; on - oncosphere; ov - ovary; sc - secondary canals; te - testes; ut - uterus; vc - vaginal canal; vd - vas deferens; vi - vitelline follicles; vo - ventral osmoregulatory canals; vs - vaginal sphincter. Scale bars: Fig. $5=100 \mu \mathrm{m}$; Figs. $6-9=250 \mu \mathrm{m}$; Fig. $10=50 \mu \mathrm{m}$. 

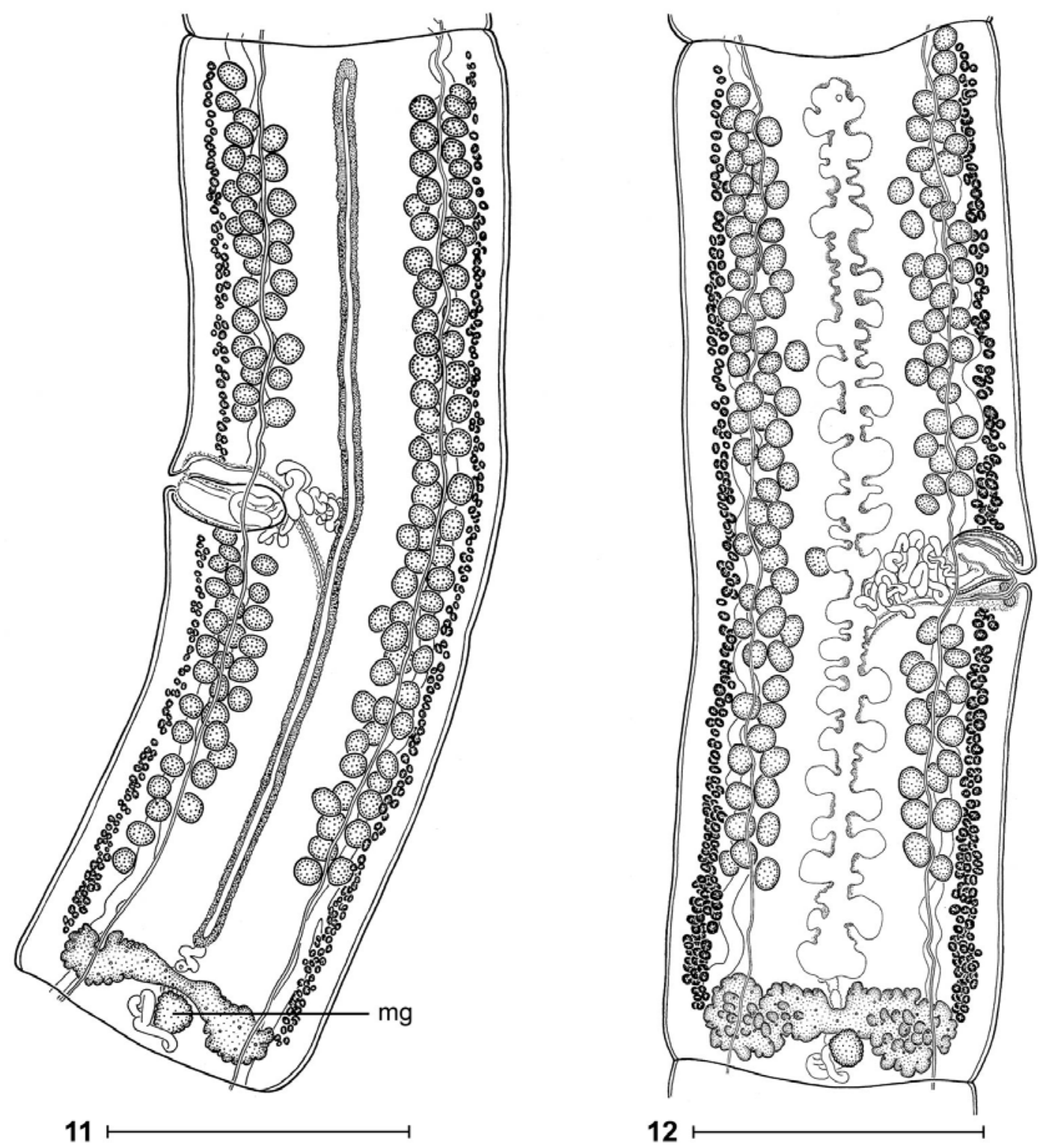

Figs. 11, 12. Ophiotaenia georgievi sp. n. Fig. 11. Holotype, mature proglottis, dorsal view (MHNG INVE 65470). Fig. 12. Paratype, pregravid proglottis, dorsal view (MHNG INVE 65473). Abbreviations: $\mathrm{mg}-$ Mehlis' glands. Scale bars $=500 \mu \mathrm{m}$.

of fish proteocephalideans, e.g. European species of the Proteocephalus aggregate (see Scholz and Hanzelová 1998) and Neotropical taxa (de Chambrier and Vaucher 1999, de Chambrier et al. 2004), proteocephalidean tapeworms parasitic in reptiles have a relatively stable, species-specific number of testes. Therefore, in this group of cestodes, the number of testes is a good discriminant character, especially when sufficient number of measurements is available (de Chambrier 1989).

Ophiotaenia ophiodex Mettrick, 1960 possesses a wider scolex (width 300-1140 vs. 225-235) and is markedly longer than O. georgievi (170-600 mm vs. $57 \mathrm{~mm}$ ). Ophiotaenia monnigi Fuhrmann, 1924 has a relatively smaller cirrus-sac (CS 10-11\% vs. 19-32\%) (Table 2). Ophio- taenia meggitti Hilmy, 1936 differs from O. georgievi by the number of uterine branches ( 35 on each side vs. 23-28 in O. georgievi), by the number of testes (81-104 vs. $92-140$ in $O$. georgievi), and by the ratio of the width of the ovary to the width of the proglottis ( $64 \%$ vs. $71-$ $76 \%$ for $O$. georgievi). The scolex of $O$. nybelini Hilmy, 1936 and O. crotaphopeltis Sandground, 1928 is smaller (width 105 and 160-180, respectively) compared to that of $O$. georgievi (225-235) and both taxa have a slightly lower number of testes (67-90 and 94-98, respectively, vs. $92-140$ in $O$. georgievi). Ophiotaenia congolensis Southwell et Lake, 1939 possesses only about 65 testes and $O$. elapsoidae Sandground, 1928 differs in a markedly higher number of uterine diverticula (48-55 vs. 23-28 


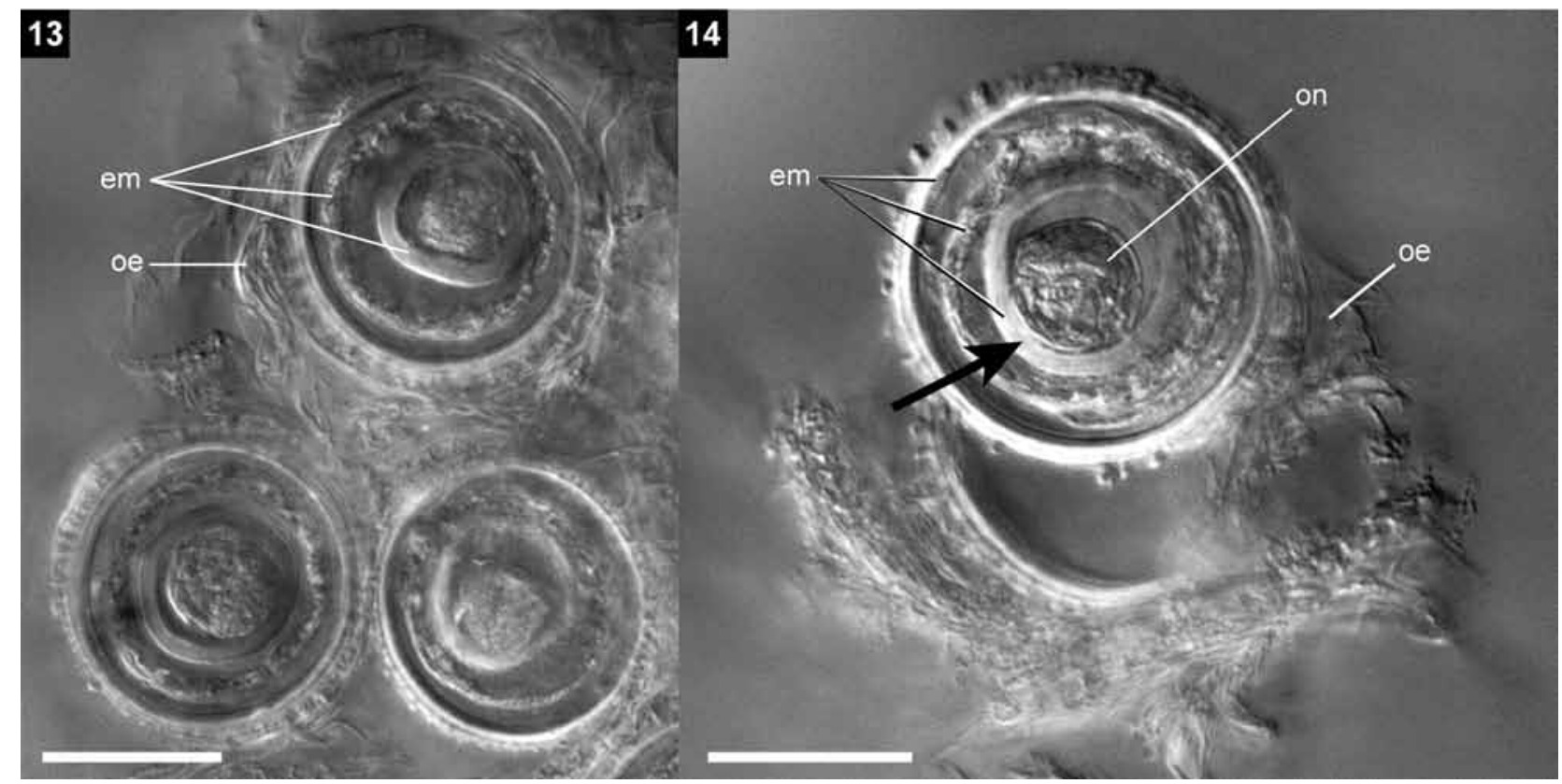

Figs. 13, 14. Ophiotaenia georgievi sp. n. Eggs in distilled water, showing the three-layered embryophore (MHNG INVE 65475); an additional layer marked by an arrow. Abbreviations: em = embryophore; oe = outer envelope; on = oncosphere. Scale bars $=20 \mu \mathrm{m}$.

in O. georgievi) (Beddard 1913, Rudin 1917, Fuhrmann 1924, Sandground 1928, Hilmy 1936, Southwell and Lake 1939, Mettrick 1960, 1963, Freze 1965).

\section{DISCUSSION}

The fauna of reptiles in Madagascar is rich with as many as 300 described species, most of them (92\%) being endemic (Vences et al. 2009). However, only one proteocephalidean cestode, Deblocktaenia ventosaloculata, was reported from reptiles in Madagascar (Schmidt 1986). This species possesses four tetraloculate suckers and parasitizes Ithycyphus miniatus (Schlegel) (Deblock et al. 1962). Up to date, no species of Ophiotaenia has been known to occur in reptiles and amphibians from the island. Therefore, O. georgievi represents the second species of proteocephalideans and the first species of Ophiotaenia from Madagascar.

However, this lack of reports on proteocephalideans seemingly reflects a low sampling effort and shortage of parasitological studies. The Brygoo's collection of tapeworms from Madagascar, based on sampling between 1961 and 1972, contains several proteocephalidean cestodes found in nine species of endemic snakes. Almost all of them belong to Ophiotaenia and probably all represent new species (unpublished data), because most species of Ophiotaenia are strictly host-specific (i.e. oioxenous sensu Euzet and Combes 1980), infecting only one species of definitive host (de Chambrier et al. 2006, Ammann and de Chambrier 2008). This assumption is also supported by observations of the senior author who has never found a proteocephalidean cestode in more than one host in any of almost 1000 snakes he examined (Ammann and de Chambrier 2008; unpublished data).

A few proteocephalideans have been reported from more than one host species, i.e. being stenoxenous sensu Euzet and Combes (1980); in most cases, morphological differences were observed between tapeworms from different hosts. For example, cestodes identified as Ophiotaenia perspicua La Rue, 1911 (type species of the genus) from several species of Natrix snakes, (e.g. Natrix rhombifer - type host, $N$. fasciata confluens, $N$. cyclopion cyclopion, N. c. floridense and N. sipedon) differed from each other in the total size, size of the scolex and eggs, relative size of the cirrus-sac, and the number of uterine diverticula (Freze 1965, Brooks 1978). These differences may indicate the existence of cryptic species within the O. perspicua complex.

Another case was reported by Rego (1962), who listed three anuran species as the definitive hosts of Ophiotaenia bonariensis Szidat et Soria, 1954. Comparison of the description of $O$. bonariensis given in Freze (1965) with that provided by Rego (1962) has shown the following differences: presence of a huge apical organ reported by Freze (1965) but not observed by Rego (1962), different number of testes (120-140 in Freze, 1965, but as many as 169 in his figure 3, whereas only 46-60 in Rego 1962), position of the vagina (always anterior to the cirrus-sac in Freze's material versus anterior or posterior, more frequently posterior to the cirrus-sac in the specimens described by Rego 1962), and size of the eggs (outer envelope $72 \mu \mathrm{m}$ versus 
Table 1. List of species of Ophiotaenia, parasites of snakes (African species in bold).

\begin{tabular}{|c|c|c|}
\hline Species & Host & Distribution \\
\hline o. adiposa Rudin, 1917 & Bitis arietans & Africa (Cameroun) \\
\hline O. agkistrodontis (Harwood, 1933) & Agkistrodon piscivorus & USA (Texas) \\
\hline O. anderseni Jensen, Schmidt et Kuntz, 1983 & Trimeresurus stejnegeri & Taiwan \\
\hline O. arandasi (Santos et Rolas, 1973) & Liophis miliaris* & Brazil \\
\hline O. azevedoi (de Chambrier et Vaucher, 1992) & Bothrops jararaca & Brazil \\
\hline O. barbouri Vigueras, 1934 & Tretanorhynchus variabilis* & Cuba \\
\hline O. calmettei (Barrois, 1898) & Bothrops lanceolatus & Martinique \\
\hline O. catzeflisi (de Chambrier et Vaucher, 1992) & Bothrops jararaca & Brazil \\
\hline O. chattoraji Srivastava, 1980 & Naja tripudians & India \\
\hline O. congolensis Southwell et Lake, 1939 & Boaedon olivaceus & Africa (Congo) \\
\hline O. crotali Lopez-Neyra et Diaz-Ungria, 1958 & Crotalus durissus terrificus & Venezuela \\
\hline O. crotaphopeltis Sandground, 1928 & Crotaphopeltis tornieri & Africa (Tanganyika Lake) \\
\hline O. dubinini Freze et Sharpilo, 1965 & Coronella austriaca* & Russia \\
\hline O. elapsoideae Sandground, 1928 & Elapsoidea guentheri & Africa (Tanganyika Lake) \\
\hline O. elongata Fuhrmann, 1927 & Colubridae gen. sp.* & Brazil \\
\hline O. europaea Odening, 1963 & Natrix natrix* & Europe \\
\hline O. euzeti (de Chambrier et Vaucher, 1992) & Bothrops jararaca & Brazil \\
\hline O. faranciae (MacCallum, 1921) & Farancia abacura* & North America \\
\hline O. fima (Meggitt, 1927) & Natrix stolata* & India \\
\hline O. fixa sp. inq. (Meggitt, 1927) & Natrix stolata* & India \\
\hline O. flava Rudin, 1917 & Coluber sp. & Brazil \\
\hline O. gabonica (Beddard, 1913) & Bitis gabonica & Africa \\
\hline O. gallardi (Johnston, 1911) & Pseudechis porphyriacus & Australia \\
\hline O. georgievi sp. n. & Leioheterodon geayi* & Madagascar \\
\hline O. gilberti Ammann et de Chambrier, 2008 & Thamnodynastes pallidus* & Paraguay \\
\hline O. grandis La Rue, 1911 & Agkistrodon piscivorus & North America \\
\hline O. habanensis Freze et Ryšavý, 1976 & Tropidophis pardalis* & Cuba \\
\hline O. hyalina Rudin, 1917 & Coluber sp.* & Brazil \\
\hline O. indica Johri, 1955 & Naja naja & India \\
\hline O. japonensis Yamaguti, 1935 & Rhabdophis tigrinus* & Japan \\
\hline O. jarara Fuhrmann, 1927 & Bothrops alternatus & Brazil \\
\hline O. joanae (de Chambrier et Paulino, 1997) & Xenodon neuwiedi* & South America \\
\hline O. kuantanensis Yeh, 1956 & Naja hannah & Malaysia \\
\hline O. lactea sp. inq. (Leidy, 1855) & Nerodia sipedon* & North America \\
\hline O. longmani sp. inq. Johnston, 1916 & Aspidites ramsayi & Australia (Roma) \\
\hline O. macrobothria Rudin, 1917 & Micrurus corallinus & Brazil \\
\hline O. marenzelleri (Barrois, 1898) & Agkistrodon piscivorus & North America \\
\hline O. meggitti sp. inq. Hilmy, 1936 & Atheris chloroechis & Liberia \\
\hline O. micruricola (Shoop et Corkum, 1982) & Micrurus diastema affinis & Mexico \\
\hline O. mjobergi (Nybelin, 1917) & Demansia psammophis & Australia \\
\hline O. monnigi sp. inq. Fuhrmann, 1924 & Crotaphopeltis hotamboeia & Africa \\
\hline O. najae (Beddard, 1913) & Naja tripudians & India \\
\hline O. nankingensis Hsü, 1935 & Zaocys dhumnades & China (Nanking) \\
\hline O. nattereri (Parona, 1901) & Coluber sp.* & Brazil \\
\hline O. nigricollis Mettrick, 1963 & Naja nigricollis & Zimbabwe \\
\hline o. nybelini Hilmy, 1936 & Coronella coronata* & Africa \\
\hline o. ophiodex Mettrick, 1960 & Causus rhombeatus & Zimbabwe \\
\hline O. paraguayensis Rudin, 1917 & Hydrodynastes gigas* & Paraguay \\
\hline O. perspicua La Rue, 1911 & Nerodia rhombifer* & North America \\
\hline O. phillipsi (Burt, 1937) & Trimeresurus trigonocephalus & Sri Lanka \\
\hline O. pigmentata sp. inq. (Linstow, 1908) & Psammodynastes pulverulentus & Java \\
\hline O. racemosa (Rudolphi, 1819) & Thamnophis sp.* & Brazil \\
\hline O. rhabdophidis (Burt, 1937) & Natrix stolata* & Sri Lanka \\
\hline O. russelli sp. inq. (Beddard, 1913) & Vipera russelli & India \\
\hline O. sanbernardinensis Rudin, 1917 & Helicops leopardinus* & Paraguay \\
\hline O. sinensis Cheng et Lin, 2002 & Rhabdophis tigrinus* & China (Fujian) \\
\hline O. southwelli Freze, 1965 & Causus rhombeatus & Africa \\
\hline O. spasskii Freze et Sharpilo, 1965 & Vipera berus & Europe \\
\hline O. theileri Rudin, 1917 & Naja haje & Africa \\
\hline O. trimeresuri (Parona, 1898) & Trimeresurus sumatrans & India \\
\hline O. variabilis (Brooks, 1978) & Nerodia cyclopion* & North America \\
\hline O. wuyiensis Cheng, Yuguang et Zao He, 2007 & Trimeresurus gramineus & China \\
\hline O. zschokkei Rudin, 1917 & Naja haje & South Africa \\
\hline
\end{tabular}

*non-venomous snakes 
Table 2. Comparative characteristics of African species of Ophiotaenia and O. georgievi sp. n.

\begin{tabular}{|c|c|c|c|c|c|c|c|c|c|}
\hline Species & $\begin{array}{l}\text { Number } \\
\text { of testes }\end{array}$ & $\mathrm{CS}$ & $\begin{array}{l}\text { Position } \\
\text { of genital } \\
\text { pore }\end{array}$ & $\begin{array}{l}\text { Position } \\
\text { of vagina } \S\end{array}$ & $\begin{array}{c}\text { Apical } \\
\text { organ }\end{array}$ & $\begin{array}{l}\text { Width of } \\
\text { scolex }\end{array}$ & $\begin{array}{l}\text { Total length } \\
\text { of body } \\
\text { (mm) }\end{array}$ & $\begin{array}{l}\text { Number } \\
\text { of uterine } \\
\text { branches } \\
\text { (each side) }\end{array}$ & $\begin{array}{c}\text { Diam- } \\
\text { eter of } \\
\text { eggs }\end{array}$ \\
\hline O. adiposa & $170-220$ & $26 \% *$ & $20-25 \%$ & ant-post & yes & $500-600$ & $300-400$ & $40-50$ & $12^{* *}$ \\
\hline O. congolensis & 65 & $25 \%$ & $44-47 \% *$ & ant-post & ? & ? & 80 & $15-20$ & 15 \\
\hline O. crotaphopeltis & $94-98$ & $14 \% *$ & $54 \% *$ & ? & no & $160-180$ & not given & $15-18$ & 26 \\
\hline O. elapsoidae & $100-125$ & $24 \% *$ & $50 \% *$ & post-ant & no & $1000-1100$ & 150 & $48-55$ & \\
\hline O. gabonica & $130-170$ & $18-20 \%$ & $42 \% *$ & usually post & no & $300-600$ & $>380$ & $38-46$ & 39 \\
\hline O. meggitti sp. inq. & $86-104$ & $33 \%$ & $50 \% *$ & usually ant & $?$ & not given & $>68$ & 35 & 25 \\
\hline O. monnigi sp. inq. & 80 & $10-11 \%$ & $51 \% *$ & ant & $?$ & no scolex & 50 & $50-57$ & 30 \\
\hline O. nigricollis & $176-210$ & $20-22 \%$ & $38 \% *$ & ant-post & no & $300-310$ & 170 & $16-20$ & $26-33$ \\
\hline O. nybelini & $67-90$ & $16-20 \%$ & $47 \% *$ & ant-post & no & 105 & 52 & $25-40$ & 25 \\
\hline O. ophiodex & $110-120$ & $22-25 \%$ & $>50 \%$ & ant-post & no & $790-1140$ & $210-270$ & $30-42$ & $27-36$ \\
\hline O. southwelli & $170-230$ & $46-50 \% *$ & $50-55 \% *$ & ant-post & no & 1500 & 90 & $8-12$ & 30 \\
\hline O. theileri & $160-310$ & $20-25 \%$ & $41-50 \% *$ & ant-post & no & 400 & estimated 300 & $35-40$ & $18 * *$ \\
\hline O. zschokkei & $160-200$ & $20-25 \%$ & $50 \%$ & usually ant & no & 400 & imated $550-600$ & & $18^{* *}$ \\
\hline O. georgievi sp. n. & $92-140$ & $19-32 \%$ & $44-56 \%$ & post-ant & no & $225-235$ & 50 & $23-28$ & $31-35$ \\
\hline
\end{tabular}

Abbreviations: CS - relative size of the cirrus-sac expressed as percentage of its length to the width of the proglottis; *taken from figures in Freze $(1965) ; * *$ diameter of oncosphere; $\S$ anterior or posterior to cirrus-sac.

$56 \mu \mathrm{m})$ and oncospheres $(20-27 \mu \mathrm{m}$ according to Freze 1965 whereas only $15 \mu \mathrm{m}$ in the material of Rego 1962).

In the Palaearctic region, Freze (1965) reported Ophiotaenia europaea Odening, 1963 from two congeneric species of snakes, Natrix natrix and Natrix tessellata. However, the average size of the testes of tapeworms from individual hosts differed, being somewhat smaller in the cestodes from $N$. tessellata (see Freze 1965).

It is obvious that future studies should confirm whether these findings actually included only one morphologically polymorphic species or more cestode taxa have been misidentified. Molecular markers may also help considerably in unravelling the actual host specificity of proteocephalidean cestodes from reptiles. Strict (stenoxenous) host specificity may also exist in species of Ophiotaenia parasitic in amphibians, as indicated by the data of de Chambrier et al. (2006), who found that each amphibian species harboured a different species of Ophiotaenia.

Another argument to assume that cestodes from the Brygoo's collection may represent new taxa is the fact that all snakes from Madagascar that harboured tapeworms are endemic. Unfortunately, most tapeworms from this collection were not well fixed or very few specimens are available, which prevents their description. It is worth mentioning that all hosts of these undescribed Ophiotaenia species are non-venomous snakes (Henkel and Schmidt 2000). In contrast, a majority (60\%) of Ophiotaenia species described up to date, especially those from the continental Africa, Latin America, tropical Asia and Australia, occur in venomous snakes (Schmidt 1986; Table 1). This discrepancy between the rich cestode fauna of non-venomous snakes in Madagascar and the depauperate fauna of cestodes parasitizing these snakes in tropical regions may be accounted for by little attention paid in parasitological studies to the latter group of reptiles.

Acknowledgements. The authors are indebted to Jean Mariaux for fruitful suggestions; they are also grateful to André Piuz for providing scanning electron micrographs and to Florence Marteau and Gilles Roth (all Geneva) for finalising the drawings. This study was supported in part by the National Science Foundation PBI award Nos. 0818696 and 0818823 , the Institute of Parasitology (projects Z60220518 and LC 522) and the Grant Agency of the Czech Republic (524/08/0885).

\section{REFERENCES}

Ammann M., de Chambrier A. 2008: Ophiotaenia gilberti sp. n. (Eucestoda: Proteocephalidea), a parasite of Thamnodynastes pallidus (Serpentes: Colubridae) from Paraguay. Rev. Suisse Zool. 115: 541-551.

Beddard F.E. 1913: Contributions to the anatomy and systematic arrangement of the Cestoidea. VII. On six species of tapeworms from reptiles, belonging to the genus Ichthyotaenia (s. 1.). Proc. Zool. Soc. Lond. 1913, Part 1: 4-36.

Brooks D.R. 1978: Systematic status of the proteocephalid cestodes of North American reptiles and amphibians. Proc. Helminthol. Soc. Wash. 45: 1-28.

De Chambrier A. 1989: Révision du genre Crepidobothrium Monticelli, 1900 (Cestoda: Proteocephalidae) parasite d'Ophidiens

néotropicaux. I. C. dollfusi Freze, 1965, C. lachesidis (MacCallum, 1921) et conclusions. Rev. Suisse Zool. 96: 345-380.

De Chambrier A. 2001: A new tapeworm from the Amazon, Amazotaenia yvettae n. gen., n. sp. (Eucestoda: Proteocephalidea) from the siluriform fishes Brachyplatystoma filamentosum and B. vaillanti (Pimelodidae). Rev. Suisse Zool. 108: 303-316.

De Chambrier A. 2006: Redescription of Kapsulotaenia sandgroundi (Carter, 1943), a parasite of Varanus komodoensis (Varanoidea: Varanidae) from Komodo Island, Indonesia. Syst. Parasitol. 63: 83-93.

de Chambrier A., Coquille S.C., Brooks D.R. 2006: Ophiotaenia bonneti $\mathrm{n}$. sp. (Eucestoda: Proteocephalidea), a parasite of 
Rana vaillanti (Anura: Ranidae) in Costa Rica. Folia Parasitol. 53: $125-133$.

de Chambrier A., Scholz T., Beletew M., Mahmoud Z.N. 2007: Proteocephalus sulcatus (Klaptocz, 1906) (Cestoda: Proteocephalidea), a poorly known parasite of Clarotes laticeps (Pisces: Siluriformes) in Africa. Rev. Suisse Zool. 114: 693-702.

de Chambrier A., Scholz T., Beletew M., Mariaux J. 2009: A new genus and species of proteocephalidean (Cestoda) from Clarias catfishes (Siluriformes: Clariidae) in Africa. J. Parasitol. 95: 160-168.

de Chambrier A., Vaucher C. 1999: Proteocephalidae et Monticelliidae (Eucestoda: Proteocephalidea) parasites de poissons d'eau douce du Paraguay avec descriptions d'un genre nouveau et de dix espèces nouvelles. Rev. Suisse Zool. 106: 165-240.

de Chambrier A., Zehnder M.P., Vaucher C., Mariaux J. 2004: The evolution of the Proteocephalidea (Platyhelminthes, Eucestoda) based on an enlarged molecular phylogeny, with comments on their uterine development. Syst. Parasitol. 57: 159-171.

CHERVY L. 2009: Unified terminology for cestode microtriches: a proposal from the International Workshops on Cestode Systematics in 2002-2008. Folia Parasitol. 56: 199-230.

Conn D.B., Świderski Z. 2008: A standardised terminology of the embryonic envelopes and associated developmental stages of tapeworms (Platyhelminthes: Cestoda). Folia Parasitol. 55: $42-52$.

Coquille S., De Chambrier A. 2008: Cairaella henrii gen. n., sp. n., a parasite of Norops trachyderma (Polychrotidae), and Ophiotaenia nicoleae sp. n. (Eucestoda: Proteocephalidea), a parasite of Thecadactylus rapicauda (Gekkonidae), in Ecuador. Folia Parasitol. 55: 197-206.

Deblock S., Rosé F., Broussart J. 1962: Ophiotaenia ventosaloculata $\mathrm{n}$. sp. parasite d'Ithycyphus miniatus (Ophidien colubridé) à Nossi-Bé. Arch. Inst. Pasteur Madagascar 31: 15-20.

Euzet L., Combes C. 1980: Les problèmes de l'espèce chez les animaux parasites. Mém. Soc. Zool. Fr. 40: 239-285.

Freze V.I. 1965: [Proteocephalata in Fish, Amphibians and Reptiles]. Essentials of Cestodology. Vol. V. Nauka, Moscow, 538 pp. (In Russian; English translation, Israel Program of Scientific Translation, 1969, Cat. No. 1853, v + 597 pp.).

Fuhrmann O. 1924: Two new species of reptilian cestodes. Ann. Trop. Med. Parasitol. 18: 505-513.

Received 22 January 2010
Henkel F.-W., Schmidt W. 2000: Amphibians and Reptiles of Madagascar and the Mascarene, Seychelles and Comoro Islands. Krieger Publishing Company, Malabar, Florida, 316 pp.

Hilmy I.S. 1936: Parasites from Liberia and French Guinea. Part III. Cestodes from Liberia. Publication of the Egyptian University, Faculty of Medicine 9: 1-72.

Marsella C.M.V., de Chambrier A. 2008: Ophiotaenia alessandrae sp. n. (Eucestoda: Proteocephalidea), a parasite of Hyla boans (Anura: Hylidae) from Ecuador. Rev. Suisse Zool. 115: 553-563.

Metтrick D.F. 1960: A new cestode, Ophiotaenia ophiodex, n. sp., from a night-adder, Causus rhombeatus (Licht.), in Southern Rhodesia. Proc. Helminthol. Soc. Wash. 27: 275-278.

MetTrick D.F. 1963: Some cestodes of reptiles and amphibians from the Rhodesias. Proc. Zool. Soc. Lond. 141: 239-250.

Rego A.A. 1962: Ocorrência de "Ophiotaenia bonariensis" Szidat \& Soria, 1954 em anfíbios anuros (Cestoda, Proteocephalidea). Rev. Bras. Biol. 22: 377-380.

Rego A.A. 1994: Order Proteocephalidea Mola, 1928. In: L.F. Khalil, A. Jones and R.A. Bray (Eds.), Keys to the Cestode Parasites of Vertebrates. CAB International, Wallingford, pp. 257-293.

Rudin E. 1917: Die Ichthyotaenien der Reptilien. Rev. Suisse Zool. 25: $14-381$.

SANDGRound J.H. 1928: Some new cestodes and nematodes parasites from Tanganyika Territory. Proc. Boston Soc. Nat. Hist. 39: $131-150$.

Schmidt G.D. 1986: CRC Handbook of Tapeworm Identification. CRC Press, Boca Raton, Florida, 675 pp.

Scholz T., Hanzelová V. 1998: Tapeworms of the genus Proteocephalus Weinland, 1858 (Cestoda: Proteocephalidae), parasites of fishes in Europe. Studie AV ČR, 1998, No. 2, 119 pp.

Scholz T., de Chambrier A., Beletew M., Mahmoud Z.N. 2009: Redescription of Proteocephalus glanduligerus (Janicki, 1928) Fuhrmann, 1933 (Cestoda: Proteocephalidea), a parasite of Clarias catfishes in Africa with a unique glandular apical organ. J. Parasitol. 95: 443-449.

Southwell T., Lake F. 1939: On a collection of Cestoda from the Belgian Congo. Ann. Trop. Med. Parasitol. 33: 107-123.

Vences M., Wollenberg K.C., Vieites D.R., Lees D.C. 2009: Madagascar as a model region of species diversification. Trends Ecol. Evol. 24: 456-465.

Accepted 17 March 2010 